\title{
РОЗРОБКА МЕТОДУ ІДЕНТИФІКАЦІЇ ЕНДОГЕННОГО РЕТРОВІРУСУ СВИНЕЙ РЕRV-С
}

\section{Т. М. РИК, О. І. МЕТЛИЦЬКА, В. Ю. НОР}

Інститут розведення і генетики тварин імені М.В.Зубия НААН (Чубинське, Україна) metlitskaya.elena110@gmail.com

Розроблена діагностична система скринінгу ендогенного ретровірусу свиней підтипу C (PERV-C) за допомогою мультиплексної ПЛP-SSP для виявлення особин із зниженим ризиком біологічної небезпеки при їх застосуванні для иілей ксенотрансплантації.

На зразках ДНК, отриманих від тварин свиней порід в'єтнамський мейшан та велика біла, визначена чутливість та специфічнність тест-системи PERV-C - $\alpha$-Actin. Bcтановлено, щзо гранично допустимою концентрацію геномної ДНК для виявлення фрагменту ретровірусу свиней в ПЛР з наступним розділенням продуктів ампліфікації иляхом горизонтального електрофорезу в агарозному гелі є 15,2 пг/мкл, а мінімальна кількість ПЛР-продукту для можливості його візуалізації склала $5 \times 10^{3}$ копій.

Ключові слова: ендогенний ретровірус свиней, PERV-C, $\alpha$-Actin, мультиплексна ПЛP-SSP, ксенотрансплантація

\section{DEVELOPMENT OF THE IDENTIFICATION'S METHOD OF PORCINE ENDOGENOUS RETROVIRUSES PERV-C}

T. M. Ryk, O. I. Metlytska, V. Y. Nor

Institute of Breeding and Animal Genetics nd. a. M.V.Zubets NAAS (Chubynske, Ukraine)

A diagnostic system for screening endogenous retrovirus of pigs of subtype $C$ (PERV-C) using multiplex PCR-SSP was developed to identify individuals with a reduced risk of biological danger when used for the purposes of xenotransplantation. The sensitivity and specificity of the PERV-C- $\alpha$ Actin test system was determined on DNA samples obtained from Vietnamese Meishan and large White pigs. It was established that the borderline admissible concentration of genomic DNA for detection of the pig retrovirus fragment in PCR, followed by separation of the amplification products by horizontal electrophoresis in a $2 \%$ agarose gel, was $15.2 \mathrm{pg} / \mu \mathrm{l}$, and the minimum amount of PCR product for visualization was $5 \times 10^{3}$ copies.

Keywords: endogenous retrovirus of pigs, PERV-C, $\boldsymbol{\alpha}$-Actin, multiplex PCR-SSP, xenotransplantation

\section{РАЗРАБОТКА МЕТОДА ИДЕНТИФИКАЦИИ ЭНДОГЕННОГО РЕТРОВИРУСА СВИНЕЙ РЕRV-С}

\section{Т. Н. Рык, Е. И. Метлицкая, В. Ю. Нор}

Институт разведения и генетики животных им. М.В.Зубиза НААН (Чубинское, Украина)

Разработана диагностическая система скрининга эндогенного ретровируса свиней подmипа C (PERV-C) с помощьью мультиплексной ПЦР-SSP для выявления особей со сниженным риском биологической опасности при их использовании для ичелей ксенотрансплантации. На образиах ДНК, полученных от свиней пород вьетнамский мейшан и крупная белая, определена чувствительность и специфичность тест-системы PERV-C- $\alpha$-Actin. Установлено, что гранично допустимой концентраџией геномной ДНК для выявления фрагмента ретровируса свиней в ПЦР с последующим разделением продуктов амплификаичи путем горизонтального электрофореза в 2\% агарозном геле является 15,2 пг/мкл, а минимальное количество ПЛРпродукта для возможности его визуализаџии составило $5 \times 10^{3}$ копий.

Розведення і генетика тварин. 2018. Вип. 55 
Ключевые слова: эндогенный ретровирус свиней, PERV-C, $\alpha$-Actin, мультиплексная ПЦРSSP, ксенотрансплантация

Вступ. Останнім часом брак донорів людських органів для пересадки в усьому світі призвів до відновлення інтересу до ксенотрансплантації клітин, тканин та органів від тварин. Розвиток біотехнології та медицини значно розширив можливості використання внутрішніх органів і тканин сільськогосподарських тварин для біомедичних цілей. В якості найбільш придатних донорів для потреб ксенотрансплантології з фізиолоічної та етичної точки зору визнано свиней свійських (Sus scrofa). Свині $\epsilon$ широко розповсюдженим видом тварин, їх вирощування і утримання не викликає особливих проблем, а внутрішні органи і системи за своїми функціями і розміром подібні до людських. Отримання генномодифікованих тварин із нокаутованими генами, що викликають реакцію надшвидкого відторгнення пересадженої тканини чи орану людині наближає до об'єктивної реальності технології ксенотрансплантації [1]. Наразі існують численні повідомлення про вдале застосування у медичній практиці ксенотрансплантацій людині острівців Лангерганса свині $[5,14,22]$. В останні роки значний прогрес трансплантаційних технологій забезпечує стійкий ефект нормоглікемії у пацієнтів з діабетом I типу із пересадженими острівцями підшлункової залози свиней, що триває понад одного року [10, 13]. Розроблена та знайшла практичного застосування пересадка нервових клітин від свині хворим на хронічні генетично обумовлені захворювання центральної нервової системи (наприклад, хвороба Паркінсона, хорея Хантінгтона, епілепсія), що резистентні до традиційних способів лікування [18]. Ефективними процедурами визнано проведення перфузії крові пацієнтів через культивовані свинячі гепатоцити [4], гемодіаліз за використання нирки і селезінки свиней та їх трансплантація [11].

Однією $з$ переваг ксенотрансплантації перед алотрансплантацією (пересадка органів і тканин від іншої особини того ж біологічного виду) є можливість більш детального обстеження донора, оскільки переважна кількість інфекцій передаються при гемотрансфузії і алотрансплантації: віруси імунодефіциту людини, гепатиту В і С, герпесу, а також туберкульоз; всього цього можна уникнути при використанні ксеногенних тканин. Однак, ксенотрансплантація провокує ризик передачі вже існуючих інфекцій тварин людям, так само як і появу нових. Суттєвого зниження ризику передачі інфекції при ксенотрансплантації можливо досягти шляхом вирощування свиней у особливих умовах, вільних від патогенів [19]. Ксенотрансплантація органів від свиней людині пов'язана 3 потенційною небезпекою зараження реципієнта ендогенними ретровірусами (porcine endogenous retrovirus (PERVs)), які є складовими частинами геномів свиней [15]. Наразі відомо три підтипи PERV: PERV-A, PERV-B i PERV-C. Типи A і $\mathrm{B}$, окрім клітинних ліній свині, можуть інфікувати деякі лінії клітин людини in vitro, a PERVС здатен до реплікації лише у клітинах свиней [17]. Проте, останнім часом з'являється інформація відносно утворення рекомбінантних вірусів PERV-A/C, що здатні до інфікування клітин людини і демонструють реплікацію з високим титром [12], що є доказом інфекційної компетентності PERV-C. Міжнародна асоціація ксенотрансплантологів створила спеціальні керуючі принципи для застосування при пересадці клітин свиней у клінічних дослідженнях: ретельний скринінг вихідного стада свиней у відношенні PERV, вибір тварин із низькими рінями експреciï PERV-A, PERV-B i, найголовніше, ідентифікація особин, які не є носіями PERV-C [21]. Аналіз PERV у різних порід свійських свиней продемонстрував високу частоту виявлення PERV типів A і В в геномах переважної більшості досліджених тварин, проте досить часто виявляються свині у яких відсутній PERV типу C [16]. Особливо це стосується аборигенних свійських порід свиней і диких кабанів [7], що може бути застосовано у програмах із збереження їх генофонду шляхом використання в якості вихідних форм при селекції спеціалізованих ліній і порід лабораторних тварин, призначених для біомедичних цілей.

Експресія PHК PERV виявлена практично у всіх порід свійських свиней. Проте секвенування ДНК повного геному свині дозволить проводити відбір тварин-донорів із зниженою ін- 
фекційною здатністю. Контроль за здатними до реплікації PERV може бути досягнутий за використання технологій ідентифікації критичних локусів ретровірусів свиней, визначення інтенсивності експресії та розробки методів їх нокауту.

Метою роботи було розробити, оптимізувати та відпрацювати методику ідентифікації ендогенного ретровірусу свиней підтипу С для оцінки рівня біологічної безпеки потенційного донорського матеріалу, що призначений для ксенотрансплантації від свиней до людини.

Матеріали і методи досліджень. Дослідження проводилися на зразках ДНК, отриманих iз крові свиней породи в'єтнамський мейшан $(\mathrm{n}=10)$ та велика біла $(\mathrm{n}=10)$ (ДПДГ «Надія», Експериментальна база Інституту свинарства і агропромислового виробництва НААН, Полтава). Для виділення геномної ДНК із зразків венозної крові був застосований сольовий метод [6]. Основні параметри отриманих нуклеїнових кислот (концентрація ДНК, ступінь їі чистоти та нативності) були виміряні за допомогою приладу NanoDrop-219 (Інститут молекулярної біології і генетики НАН, Київ). Перед проведенням вимірювань еталонний зразок ДНК розводили дистильованою водою у 40 разів (до 5 мл розчину екстрагованої ДНК додавали 195 мл дистильованої води). Вимірювання поглинання при довжині хвилі 260 нм проводили в кюветі із довжиною оптичного шляху 1 мм, застосовуючи бідистильовану воду в якості референтної проби у десяти повторностях. Значення концентрації ДНК у еталонному зразку розраховували шляхом множення значення поглинання при довжині хвилі 260 нм на коефіцієнт поглинання 50.

Генотипування проводили методом алель-специфічної (ПЛР-SSP) мультиплексної полімеразної ланцюгової реакції. Використовували праймери, комплементарні ділянці локусу PERV-C [8], в якості внутрішнього контролю ПЛР використовували фрагмент локусу альфаактину свині свійської ( $\alpha$-Actin) [9] (табл. 1).

1. Структура олігонуклеотидних послідовностей для ідентифікації ендогенного ретровірусу свиней підтипу $C$

\begin{tabular}{|c|c|c|c|}
\hline №№ 3/П & Назва локусу & Структура праймерів & $\begin{array}{l}\text { Розмір фрагменту, } \\
\text { П.н. } \\
\end{array}$ \\
\hline \multirow{2}{*}{11.} & \multirow{2}{*}{ PERV-C } & Forward: 5'- CTGACCTGGATTAGAACTGG -3' & \multirow{2}{*}{281} \\
\hline & & Reverse: 5'- ATGTTAGAGGATGGTCCTGG -3' & \\
\hline \multirow{2}{*}{2.} & \multirow{2}{*}{$\alpha$ - Actin } & Forward: 5'- CGCCATGTGTGACGAAGACGAGACC -3' & \multirow{2}{*}{516} \\
\hline & & Reverse: 5'- CACGTACATGGCGGGCACGTTGAAG -3' & \\
\hline
\end{tabular}

Електрофоретичне розділення ампліфікованих ділянок ДНК у форматі мультиплекс ПЛР проводилось у 2\%-му агарозному гелі у тріс-боратному електрофорезному буфері (TВЕ: 0,0879 М Тріс, 0,089 М борна кислота, 0,002 М ЕДТА рН 8,0), згідно методичних рекомендацій [2]. Для контролю за розмірами отриманих в результаті ампліфікації фрагментів використовували маркер молекулярної розміру Thermo Scientific O'GeneRuler 100 bp DNA Ladder, що дозволяє проводити контроль за розмірами ДНК-фрагментів у діапазоні молекулярних розмірів від 100 до 1000 п.н.

Значення «Genome copy number» (мінімальна кількість копій фрагменту ДНК для можливості його візуалізації) розраховували за наступною формулою [20]:

$$
\text { Genome copy number }=\frac{\text { amount of genome }(\mu \mathrm{l}) \times \text { Avogadro constant }\left(\mathrm{mol}^{-1}\right)}{\text { length of DNA }(\mathrm{bp}) \times 10^{6} \times 650},
$$

де Amount of genome $(\mu \mathrm{l})$ - концентрація ДНК-зразка,

Avogadro constant $\left(\mathrm{mol}^{-1}\right)$ - константа Авогадро,

Length of DNA (bp) - довжина ДНК (свині свійської) - $2800 \mathrm{MB}=2,8 \times 10^{9}$ п.н.

Загальна кількість проведених ПЛР склала - 125. 


\section{Результати досліджень.}

\section{Оптимізація техніки генотипування свиней в мультиплексній ПЛР-SSP системі PERV-C - $\alpha$-Actin (LAPC)}

Початковим етапом у роботі було відпрацювання та доведення до максимально оптимальних умов процесу ПЛР. Була емпірично створена програма ампліфікації шляхом теоретичного розрахунку середньої температури випалювання праймерів, згідно їх відомої нуклеотидної структури та співвідношення пурінів і пірімідінів: $95^{\circ} \mathrm{C}-2 \mathrm{xв} ; 35$ циклів: $95^{\circ} \mathrm{C}-30 \mathrm{c}$, $65^{0} \mathrm{C}-30$ с, $72^{0} \mathrm{C}-3$ хв., $72^{0} \mathrm{C}-5$ хв. Більш висока чутливість переважної кількості комерційних лабораторних тест-систем визначення вірусного навантаження забезпечується високим загальним об'ємом реакційної суміші 25-40 мкл, проте для зниження собівартості одного визначення генотипу свиней за геномним ретровірусом PERV-C було проведене лабораторне дослідження можливості проведення ПЛР у 15 мкл загального об'єму реакційної суміші. Проведено паралельне дослідження роботи діагностичної системи PERV-C у двух об'ємах реакційної ПЛР суміші - 15 мкл та 25 мкл з робочою концентрацією праймерів LAPC та PERV-C $20 \mathrm{pMol} / \mu \mathrm{l}$ за наступними схемами (табл. 2).

\section{2. Схема компонентного складу реакційної сумімі для проведення} ампліфікації фрагменту ретровірусного гена свиней PERV-C

\begin{tabular}{|c|c|c|c|}
\hline Компоненти реакційної суміші & Кількість, мкл & Компоненти реакційної суміші & Кількість, мкл \\
\hline $\mathrm{H}_{2} \mathrm{O}$ & 8 & $\mathrm{H}_{2} \mathrm{O}$ & 13,8 \\
\hline 10xPCR-buf, & 1,6 & 10xPCR-buf, & 2,5 \\
\hline dNTP & 1,6 & dNTP & 2,5 \\
\hline $\mathrm{MgCl}_{2}$ & 1,3 & $\mathrm{MgCl}_{2}$ & 2 \\
\hline PrLAPC-FW & 0,6 & PrLAPC-FW & 1 \\
\hline PrLAPC-RV & 0,6 & PrLAPC-RV & 1 \\
\hline PrPERV-C- FW & 0,3 & PrPERV-C- FW & 0,5 \\
\hline PrPERV-C-RV & 0,3 & PrPERV-C-RV & 0,5 \\
\hline TaqPol & 0,1 & TaqPol & 0,2 \\
\hline DNA & 0,6 & DNA & 1 \\
\hline Загальний об’єм & 15 & Загальний об’єм & 25 \\
\hline
\end{tabular}

У подальших дослідженнях використовували схему ПЛР з об'ємом реакційної суміші 15 мкл. Після візуалізації продуктів ампліфікації на електрофореграмі (рис. 1) було визначено, що робоча концентрація праймерів $20 \mathrm{pMol} / \mu 1$ виявилася завеликою, оскільки значна їхня кількість не застосовується при синтезі необхідних ПЛР-продуктів і призводить до нераціонального використання реагентів.

Зменшення робочої концентрації праймерів з $20 \mathrm{pMol} / \mu \mathrm{l}$ до $10 \mathrm{pMol} / \mu 1$, дало змогу усунути вищезазначені недоліки.

Наступне завдання, яке потребувало вирішення - усунення неспецифічних продуктів ПЛР, що проявляються під час візуалізації електрофореграм та ускладнюють точність діагностики за PERV-C. Одним з шляхів вирішення проблеми, на нашу думку, могло б бути підвищення температури випалювання праймерів $3+65^{\circ} \mathrm{C}$ до $+67^{0} \mathrm{C}$.

Підвищення температури випалювання праймерів до $+67^{\circ} \mathrm{C}$ негативно позначилося на процесі мультиплекс ПЛР PERV-C - $\alpha$-Actin, оскільки фрагмента PERV-C (281 п.н.) не синтезувався у жодній пробі, на відміну від внутрішнього контролю ампліфікації - $\alpha$-Аctin (516 п.н.). Тому у подальшому використовувалася вихідна програма ампліфікації з температурою випалювання праймерів $+65^{\circ} \mathrm{C}$. 


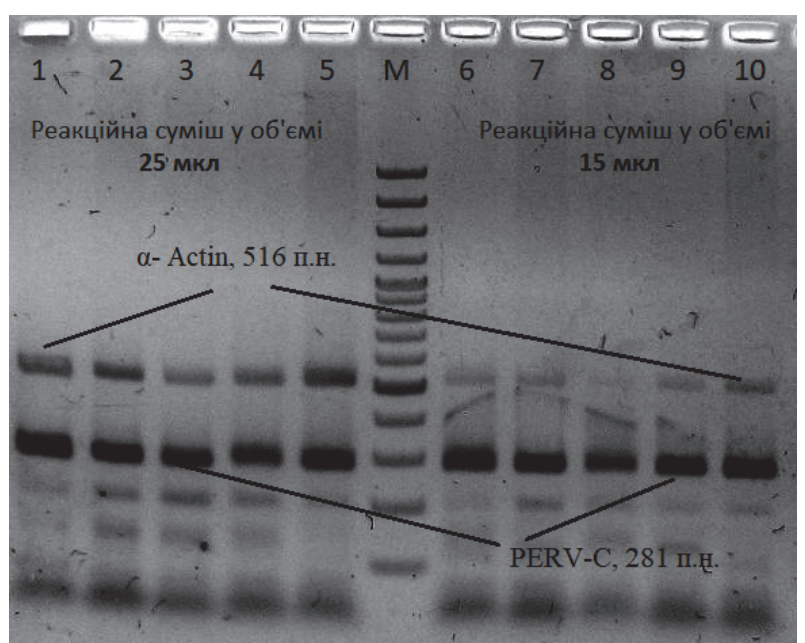

Рис. 1 Електрофореграма розділення у $2 \%$ агарозному гелі продуктів мультиплексної ПЛР PERV-C - a-Actin (LAPC) за схемою у 25 мкл об'ємі реакційної суміші. М - маркер молекулярного розміру, 1-5 - продукти мультиплекс ПЛР PERV-C - a-Actin (LAPC) ДНК свиней породи в'єтнамський мейшан за об'єму реакційної суміші 25 мкл; 6-10 - продукти мультиплекс ПЛР PERV-C - a-Actin (LAPC) ДНК свиней породи в'єтнамський мейшан за об'єму реакційної суміші 15 мкл.

Одним із способів підвищення специфічності гібридизації олігонуклеотидних послідовностей з тотальною ДНК є зміна концентрації такого компоненту реакційної суміші ПЛР як $\mathrm{MgCl}_{2}$ у бік ії зменшення. Тому наступна серія дослідів стосувалася вибору оптимальної схеми ПЛР, де лімітуючим фактором була концентрація $\mathrm{MgCl}_{2}$. Ми зупинилися на трьох величинах кількості $\mathrm{MgCl}_{2}$ у реакційній суміші - 1,3 мкл, 1 мкл та 0,6 мкл (рис 2.).

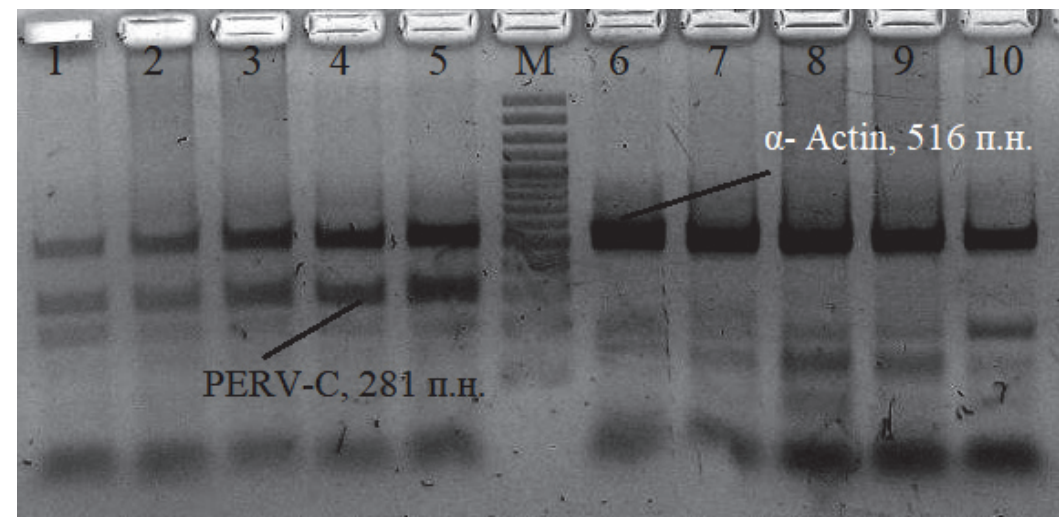

Рис. 2 Електрофорез у 2\% агарозному гелі продуктів мультиплекс ПЛР PERV-C - $\alpha$-Actin (LAPC). М - маркер молекулярної маси, 1-5 - продукти мультиплекс ПЛР PERV-C - a-Actin (LAPC) ДНК свиней породи в'стнамський мейшан за кількості1,3 мкл $\mathrm{MgCl}_{2}$ у реакціній суміші; 6-10 - продукти мультиплекс

ПЛР PERV-C - $\alpha$-Actin (LAPC) ДНК свиней породи в’єтнамський мейшан за кількості 1 мкл $\mathrm{MgCl}_{2}$ у реакційній суміші

Зменшення кількості $\mathrm{MgCl}_{2}$ у реакційній суміші для ПЛР негативно вплинуло на синтез фрагменту PERV-C (281 п.н.), оскільки олігонуклеотидні послідовності не змогли гібридизуватися з геномною ДНК свині, амплікон зазначеного розміру не візуалізувався на електрофреграмі (табл. 3). Таким чином, емпіричним шляхом була визначена оптимальна кількість $\mathrm{MgCl}_{2}$ (1,3 мкл) у реакційній суміші для проведення мультиплексної ПЛР PERV-C - $\alpha$-Actin. Heобхідно відмітити, що при створенні власних методик ідентифікації певних фрагментів генів будьяких біологічних об'єктів, використання ПЛР-буфера, що містить у своєму складі $\mathrm{MgCl}_{2} \mathrm{He} \epsilon$ бажаним, оскільки не дає можливості варіювати із концентрацією іонів магнію для запобігання появи неспецифічних фрагментів синтезу. 
3. Компонентний склад реакційної суміші для визначення фрагменту геномного ретровірусу PERV-C свиней

\begin{tabular}{|c|c|}
\hline Компоненти реакційної суміші & Концентрація, мкл \\
\hline $\mathrm{H}_{2} \mathrm{O}$ & 7 \\
\hline buf & 1,6 \\
\hline dNTP & 1,6 \\
\hline $\mathrm{MgCl}_{2}$ & 1,3 \\
\hline PrLAPC-FW & 0,6 \\
\hline PrLAPC-RV & 0,6 \\
\hline PrPERV-C- FW & 0,6 \\
\hline PrPERV-C-RV & 0,6 \\
\hline TaqPol & 0,1 \\
\hline DNA & 1 \\
\hline Загальний об' $€ \mathrm{M}$ & 15 \\
\hline
\end{tabular}

В результаті проведення серії лабораторних експериментів 3 визначення оптимальних режимів ампліфікації продуктів мультиплексної ПЛР PERV-C - $\alpha$-Actin були виведені наступні методичні параметри:

1. Для отримання специфічних продуктів синтезу ДНК-мішені, реакційна суміш для проведення реакції ампліфікації загальним об' ємом 15 мкл повинна містити робочу концентрацію праймерів $\alpha$-Actin LAPC - $20 \mathrm{pMol} / \mu 1$ и PERV-C - $10 \mathrm{pMol} / \mu \mathrm{l}$.

2. Програма ампліфікації для створеної тест-системи у форматі мультиплекс проводиться в температурному режимі: $95^{\circ} \mathrm{C}-2$ хв.; 35 циклів: $95^{\circ} \mathrm{C}-30 \mathrm{c}, 65^{\circ} \mathrm{C}-30$ c, $72^{\circ} \mathrm{C}-3$ хв., $72^{0} \mathrm{C}-5$ хв.

3. Оптимум компонентного складу реакційної суміші із розрахунку на загальний об’єм 15 мкл, наведений в табл. 2.

4. Розділення продуктів ПЦР необхідно проводити у $2 \%$ агарозному гелі, 3 нанесенням 10 мкл ПЛР продукту та 3 мкл барвника (бромфеноловий синій / ксилолціанол). Тривалість проходження електрофорезу становить близько 30 хв. за потужності електричного поля у 12 Вт (рис. 3).

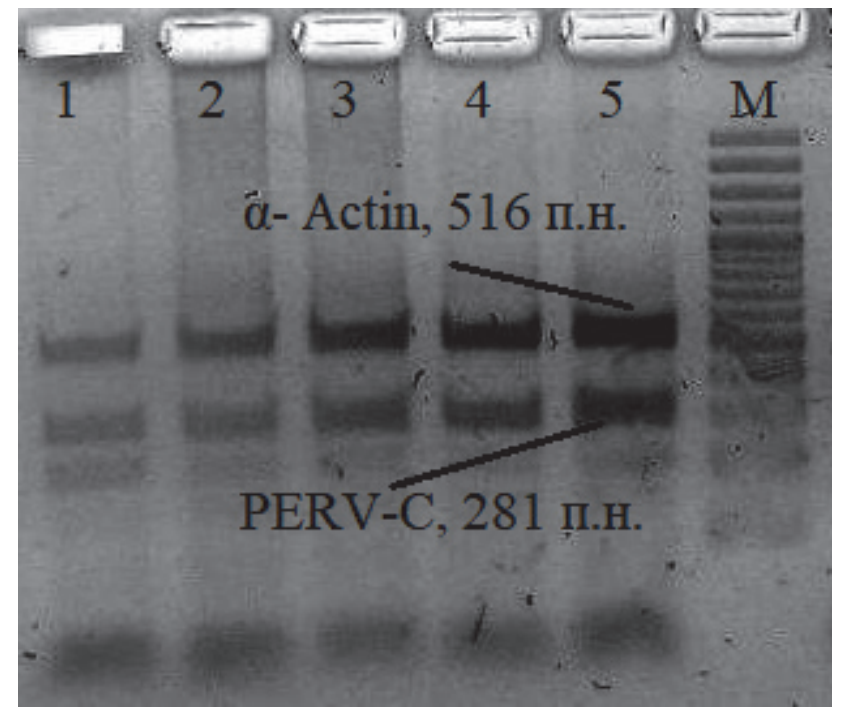

Рис. 3 Електрофорез у 2\% агарозному гелі продуктів мультиплекс ПЛР PERV-C - a-Actin (LAPC) за оп-тимально підібраних умов ПЛР. М - маркер молекулярного розміру, 1-5 - продукти мультиплекс ПЛР PERV-C - $\alpha$-Actin (LAPC) ДНК свиней породи в'стнамський мейшан 


\section{Чутливість та специфічність системи PERV-C - $\alpha$-Actin.}

Експериментальним шляхом була виявлена певна чутливість системи PERV-C на зразках ДНК свиней великої білої породи (особини якої за літературними даними переважно є носіями ретровірусу підтипу С) за використання вже оптимізованої та відпрацьованої схеми ПЛР в системі мультиплекс. Було проведене визначення наявності фрагменту гена PERV-C у десяти особин великої білої породи у створеній системі мультиплекс, всі досліджені тварини виявилися носіями цього типу ендогенного ретровірусу. У подальшому ці ж самі зразки ДНК були взяті для ПЛР, де використовувалися лише праймери PERV-C без внутрішнього контролю ампліфікації, яким виступав локус $\alpha$-Actin. Електрофоретичне розділення продуктів PERV-C aмпліфікації показав, що усі піддослідні тварини виявилися носіями PERV-C, а різна інтенсивність забарвлення смуг фрагменту 281 п.н. вказує на кількість синтезованого ПЛР-продукту, що суттєво відрізнявся в залежності від обраної проби (рис. 4). Очевидно, що інтенсивність флуоресценції ампліфікованого фрагменту PERV-C залежить від ступеня вірусного навантаження - кількості копій цільового фрагмента у геномній ДНК свині [3]. В подальших дослідженнях, безперечно важливим методичним завданням буде не тільки створення системи ідентифікації ендогенних ретровірусів, що $є$ лімітуючими факторами при ксенотранслантації, але і вибір сучасних методів проведення полімеразної ланцюгової реакції із флуоресцентно міченими праймерами в режимі реального часу для визначення кількості синтезованої ДНК-мішені, а отже відносної кількості PERV-C в геномі свиней.

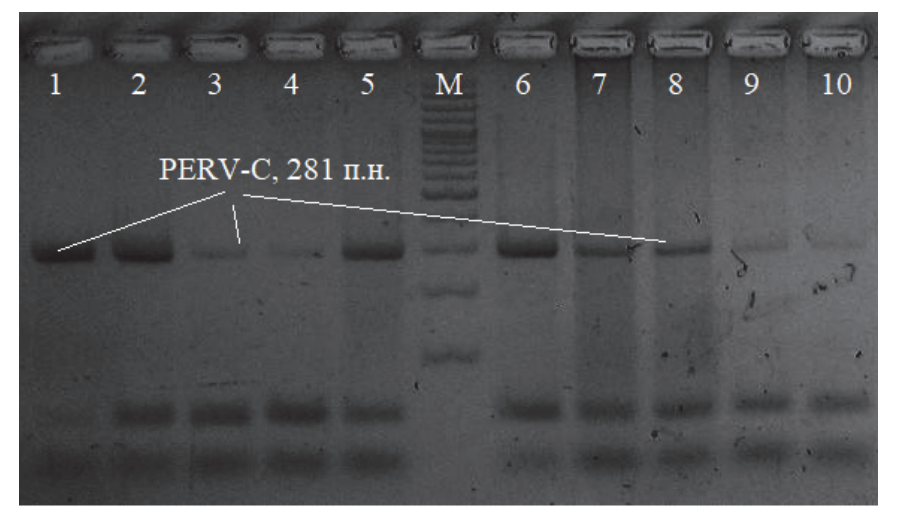

Рис. 4 Електрофорез у 2\% агарозному гелі продуктів ПЛР PERV-C. М - маркер молекулярного розміру, 1-10 - продукти ПЛР PERV-С ДНК свиней великої білої породи за оптимально підібраних умов ПЛР

Для того, щоб продемонструвати чутливість і специфічність праймерів до ділянки ендогенного ретровірусу свиней підтипу C, було проведено дослідження по встановленню мінімально необхідної концентрації ДНК для можливості детекції ПЛР PERV-C (281 п.н.). Для цього був обраний зразок ДНК свині породи в’єтнамський мейшан, що містив у своєму складі фрагмент PERV-C (281 п.н.). За допомогою спектрофотометрії були виміряні основні параметри даного зразка у десяти повторностях, а саме: ступінь чистоти та нативності ДНК (табл. 4), проведене визначення середнього значення її концентрації у розчині.

Досліджений зразок ДНК мав високу ступінь чистоти та нативності, а його концентрація склала близько 152,16 нг/мкл. Оптимальним значенням чистоти ДНК і показником відсутності інгібіторів ПЛР реакції (солей, білків та РНК) є співвідношення 260/280 що дорівнює 1,8-1,9 [2]. В нашому досліді, було отримано значення 260/280, на рівні 1,92, що свідчить про високу якість отриманого розчину екстрагованої ДНК.

Виходячи з отриманих даних, була розпочата робота з пошуку гранично допустимої (найменшої) концентрації ДНК, яким повинен володіти зразок, для можливості детекції мультиплекс ПЛР PERV-C - $\alpha$-Actin шляхом візуалізації електрофореграм. Для цього у дослідженому еталонному зразку ДНК свині породи в'єтнамський мейшан (умовно позначений як 1:1) знижували ії концентрацію шляхом додавання дейонізованої води за наступними пропорціями: $1: 1,1: 2,1: 3,1: 4,1: 5,: 10,1: 100,1: 1000,1: 10000,1: 20000,1: 30000,1: 50000,1: 100000$. У 
4. Основні спектрофотометричні параметри еталонного зразка ДНК свині породи в'єтнамський мейчан

\begin{tabular}{|c|c|c|c|c|c|c|c|c|}
\hline $\begin{array}{c}\text { Номер } \\
\text { проби }\end{array}$ & Дата і час & Концентрація & $\begin{array}{c}\text { Одиниці } \\
\text { виміру }\end{array}$ & A260 & A280 & $260 / 280$ & $260 / 230$ & $\begin{array}{c}\text { Нуклеїнова } \\
\text { кислота }\end{array}$ \\
\hline 1 & $\begin{array}{c}23.03 .2017 \\
14: 20: 46\end{array}$ & 148,9 & $\mathrm{ng} / \mu \mathrm{l}$ & 2,977 & 1,546 & 1,93 & 2,05 & DNA \\
\hline 2 & $\begin{array}{c}23.03 .2017 \\
14: 21: 46\end{array}$ & 151,3 & $\mathrm{ng} / \mu \mathrm{l}$ & 3,026 & 1,584 & 1,91 & 1,99 & DNA \\
\hline 3 & $\begin{array}{c}23.03 .2017 \\
14: 22: 34\end{array}$ & 152,5 & $\mathrm{ng} / \mu \mathrm{l}$ & 3,051 & 1,600 & 1,91 & 1,98 & DNA \\
\hline 3 & $\begin{array}{c}23.03 .2017 \\
14: 23: 15\end{array}$ & 150,0 & $\mathrm{ng} / \mu \mathrm{l}$ & 3,000 & 1,562 & 1,92 & 2,02 & DNA \\
\hline 4 & $\begin{array}{c}23.03 .2017 \\
14: 24: 18\end{array}$ & 158,5 & $\mathrm{ng} / \mu 1$ & 3,170 & 1,683 & 1,88 & 1,89 & DNA \\
\hline 5 & $\begin{array}{c}23.03 .2017 \\
14: 25: 01\end{array}$ & 151,4 & $\mathrm{ng} / \mu 1$ & 3,028 & 1,579 & 1,92 & 2,01 & DNA \\
\hline 6 & $\begin{array}{c}23.03 .2017 \\
14: 25: 45\end{array}$ & 151,5 & $\mathrm{ng} / \mu 1$ & 3,031 & 1,578 & 1,92 & 1,99 & DNA \\
\hline 7 & $\begin{array}{c}23.03 .2017 \\
14: 26: 47\end{array}$ & 150,1 & $\mathrm{ng} / \mu 1$ & 3,002 & 1,565 & 1,92 & 1,96 & DNA \\
\hline 9 & $\begin{array}{c}23.03 .2017 \\
14: 27: 32\end{array}$ & 155,5 & $\mathrm{ng} / \mu 1$ & 3,111 & 1,619 & 1,92 & 1,97 & DNA \\
\hline 10 & $\begin{array}{c}23.03 .2017 \\
14: 28: 08\end{array}$ & 151,9 & $\mathrm{ng} / \mu 1$ & 3,038 & 1,584 & 1,92 & 2,00 & DNA \\
\hline \multicolumn{2}{|c|}{ В середньому } & 152,16 & $\mathrm{ng} / \mu \mathrm{l}$ & 3,043 & 1,590 & 1,92 & 1,99 & DNA \\
\hline
\end{tabular}

подальшому з усіма варіантами концентрацій досліджуваного зразка проводилась мультиплексна ПЛР PERV-C - $\alpha$-Actin. Результати досліджень представлені на електрофореграмах (рис. 5,6 ), де в якості позитивного контролю виступала проба 1:1.

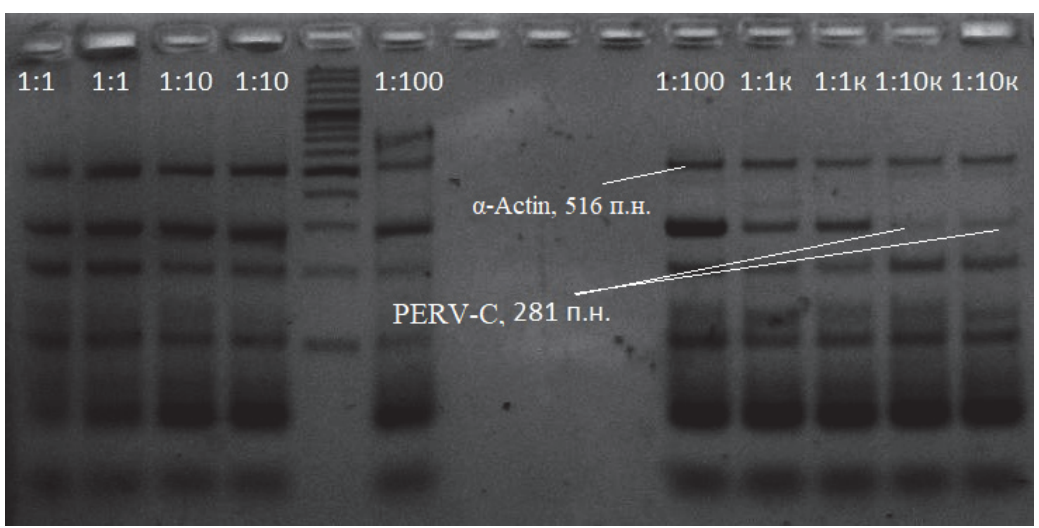

Рис. 5 Електрофорез у 2\% агарозному гелі продуктів мультиплекс ПЛР PERV-C - a-Actin. M - маркер молекулярного розміру, 1:1 - 1:10к - продукти мультиплекс ПЛР PERV-C - a-Actin свиней породи в'єTнамський мейшан за різної концентрації ДНК.

Таким чином, було показано, що розведення вихідного зразку ДНК (1:1 - 152 нг/мкл) до 1:10000 $\left(152 \times 10^{-4}\right.$ нг/мкл або 15,2 пг/мкл) є гранично допустимим для можливості детекції мультиплекс ПЛР PERV-C - $\alpha$-Actin методом горизонтального электрофорезу у $2 \%$ агарозі.

На основі отриманого значення мінімально допустимої концентрації ДНК для мультиплекс ПЛP PERV-C - $\alpha$-Actin було розраховано значення «Genome copy number» (мінімальна кількість копій ПЛР-продукту для його детекції): 


$$
\begin{gathered}
\text { Genome copy number }=\frac{\text { amount of genome }(\mu \mathrm{l}) \times \text { Avogadro constant }\left(\mathrm{mol}^{-1}\right)}{\text { length of DNA }(\mathrm{bp}) \times 10^{6} \times 650}=\frac{152 \times 10^{-4} \times 6.022 \times 10^{23}}{2,8 \times 10^{9} \times 10^{6} \times 650} \\
=5 \times 10^{3} .
\end{gathered}
$$

Отже, мінімально необхідна кількість копій ПЛР-продукту системи PERV-C - $\alpha$-Actin для візуалізації методом електрофорезу у $2 \%$ агарозі складає $5 \times 10^{3}$.

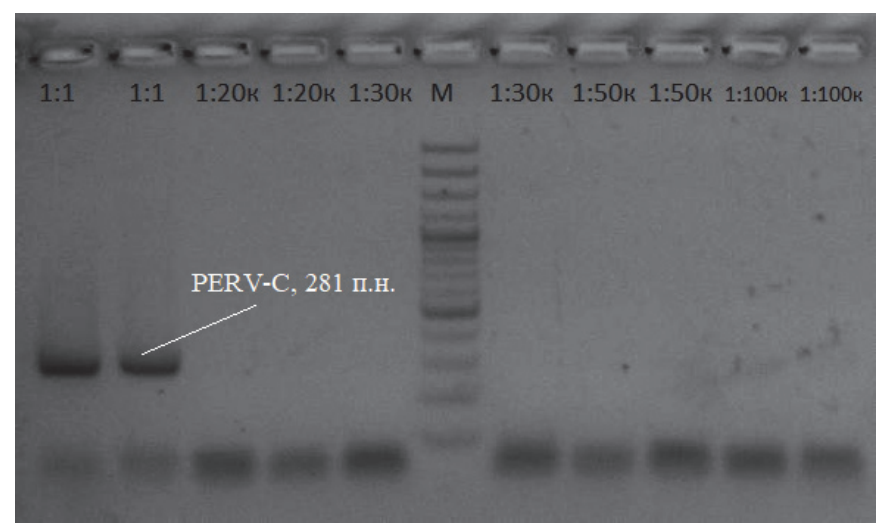

Рис. 6 Електрофорез у 2\% агарозному гелі продуктів мультиплекс ПЛР PERV-C - a-Actin. М - маркер молекулярного розміру, 1:1 - 1:100к - продукти мультиплекс ПЛР PERV-C - $\alpha$ Actin свиней породи в’єтнамський мейшан за різної концентрації ДНК.

Висновки. За результатами проведених молекулярно-генетичних генетичних досліджень розроблена система діагностики тварин-носіїв ендогенного ретровірусу свиней підтипу С за допомогою мультиплексної ПЛP-SSP PERV-C - $\alpha$-Actin. Відпрацювання та оптимізація техніки генотипування на свинях породи в'єтнамський мейшан та велика біла визначило оптимальні параметри схеми ПЛР, програми ампліфікації та режимів електрофоретичного розділення фрагментів з подальшою їхньою візуалізацією, а також дало змогу встановити гранично допустиму концентрацію ДНК для ПЛР, що склала 15,2 пг/мкл, та мінімальну кількість ПЛР-продукту для можливості його візуалізації $-5 \times 10^{3}$ копій.

\section{БІБЛІОГРАФІЯ}

1. Использование трансенных Gal-ко свиней в ксенотрансплантации: проблемы и перспективы / Н. А. Зиновьева, А. В. Мелерзанов, Е. В. Петерсен, Н. Климюк, Н. А. Волкова, А. С. Дух, И. А. Трусова, Э. Вольф, Г. Брем // Сельскохозяйственная биология. - 2014. № 2. - С. 42-49.

2. Маниатис, Т. Молекулярное клонирование / под ред. Баева А. А. - пер. с англ. / Т. Маниатис, Э. Фрич, Д. Сембрук // М. : Мир. - 1984. - 479 с.

3. Определение числа копий эндогенных ретровирусов типа А у домашних свиней и диких кабанов / Р. Б. Айтназаров, Н. С. Юдин Р. С. Кирильчук, Н. Н. Кочнев, С. П. Князев, М. И. Воевода // Вавиловский журнал генетики и селекции. - 2016. - Т. 20, № 6. - С. 756- 761.

4. Рябинин, В. Е. Проблемы и перспективы создания экстракорпоральных систем поддержки функционального состояния печени / В. Е. Рябинин // Биомедицинская химия. 2015. - Т. 61, вып. 5. - С. 545-559.

5. Скалецкий, Н. Н. Влияние культивирования островковых клеток поджелудочной железы на их выживание в организме ксеногенного реципиента / Н. Н. Скалецкий // Трансплантация органов. - К., 1985. - С. 219-220.

6. Соколов, В. П. Выделение высокомолекулярной эукариотической ДНК с использованием ацетата калия / В. П. Соколов, В. В. Джемелинский // Молекулярная генетика, микробиология и вирусология. - 1989. - Т. 6. - С. 45-46. 
7. Юдин, Н. С. Эндогенные ретровирусы свиньи: насколько велик риск инфекции при ксенотрансплантации? / Н. С. Юдин, Р. Б. Айтназаров, В. И. Ермолаев // Вавиловский журнал генетики и селекции. - 2011. - Т. 15, № 2. - С. 340-350.

8. Characterization of PERV in a new conserved pig herd as potential donor animals for xenotransplantation in China/ Fei Guo, Xiaowei Xing, Wayne J Hawthorne, Qiong Dong, Bin Ye, Juan Zhang, Qi Liang, Wei Nie // Virology Journal. - 2014. - V. 11. - P. 212-221.

9. Characterization of swine leukocyte antigen polymorphism by sequence-based and PCR-SSP methods in Meishan pigs / Ho Chak-Sum, S. Erin, P. Rochelle, W. Gregory, M. Martens, B. Lawrence, J. Schook, M. Douglas, M. Smith // Immunogenetics. - 2006. - V. 58, № 11. - P. 873-882.

10. Clinical Islet Xenotransplantation How Close Are We? / D. J Windt, R. Bottino, G. Kumar G., M. Wijkstrom, H. Hara, M. Ezzelarab, B. Ekser, C. Phelps, M. Murase, A. Casu, D. Ayares, G. Fadi, R. Lakkis, M. Trucco, D. Cooper // Diabetes. - 2012. - V. 61, № 12. - P. 3046-3055.

11. Contribution of Large Pig for Renal Ischemia-Reperfusion and Transplantation Studies: The Preclinical Model / S. Giraud, F. Favreau, N. Chatauret, R. Thuillier, S. Maiga, T. Hauet // Biomedicine and Biotechnology. - 2011. - V. 2011. - P. 1-14.

12. Determinants of high titer in recombinant porcine endogenous retroviruses / I. Harrison, Y. Takeuchi, B. Bartosch, J. P. Stoye // J. Virol. - 2004. - V. 78. - P. 13871-13879.

13. Elliott, R. B. Living Cell Technologies Towards xenotransplantation of pig islets in the clinic / R. V. Elliott // Curr Opin Organ Transplant. - 2011. -V. 16. - P. 195-200.

14. Groth, C. G. Transplantation of porcine fetal pancreas to diabetic patients / C. G. Groth, O. Korsgren, A. Tibell // Lancet. - 1994. - V. 344. - P. 1402-1404.

15. Meije, Y. Retroviral restriction factors and infectious risk in xenotransplantation / Y. Meije, R. R. Tonjes, J. A. Fishman // Am. J. Transplant. - 2010. - V. 10, № 7. - P. 1511-1516.

16. Nikitin, S. V. Differentiation of wild boar and domestic pig populations based on the frequency of chromosomes carrying endogenous retroviruses / S. V. Nikitin, N. S. Yudin, S. P. Knyazev // Nat. sci. - 2010. - V. 2, № 6. - P. 527-534.

17. Porcine endogenous retroviruses in xenotransplantation - molecular aspects / M. C. Kimsa, B. Strzalka-Mrozik, M. W. Kimsa, J. Gola, P. Nicholson, K. Lopata, U. Mazurek // Viruses. 2014. - V. 6, № 5. - P. 2062-2083.

18. Porcine xenografts in Parkinson's disease and Huntington's disease patients: preliminary results / J.S. Fink, J. M Schumacher, S. L. Ellias, E. P. Palmer, M. SaintHilaire, K. Shannon, R. Penn, P. Starr, C. Van Horne, H. S. Kott, P. K. Dempsey, A. J. Raineri, C. Manhart, J. Dinsmore, O. Isacson // Cell Transplant. - 2000. - V. 9, № 2. - P. 273-278.

19. Production of cloned NIBS (Nippon Institute for Biological Science) and $\alpha-1,3$-galactosyltransferase knockout MGH miniature pigs by somatic cell nuclear transfer using the NIBS breed as surrogates / Y. Shimatsu, K. Yamada, W. Horii, A. Hirakata, Y. Sakamoto, S. Waki, J. Sano, T. Saitoh, H. Sahara, A. Shimizu, H. Yazawa, D. H. Sachs, T. Nunoya // Xenotransplantation. 2013. - V. 20, № 3. - P. 157-164.

20. Stephenson, F. H. Calculations for Molecular Biology and Biotechnology A Guide to Mathematics in the Laboratory / F .H. Stephenson // Elsevier Inc. - 2003. - 302 p.

21. The international xenotransplantation association consensus statement on conditions for undertaking clinical trials of porcine islet products in type 1 diabetes-executive summary / B. J. Hering, D. K. Cooper, E. Cozzi, H. J. Schuurman, G. S. Korbutt, J. Denner, P. J. O'Connell, H. Y. Vanderpool, R. N. Pierson // Xenotransplantation. - 2009. - V. 16. - P. 196-202.

22. Valdés-González, R. A. Xenotransplantation of porcine neonatal islets of Langerhans and Sertoli cells: a 4-year study/ R. A. Valdés-González, L. M. Dorantes, G. N. Garibay // Eur. J. Endocrinol. $-2005 .-$ V. 153. - P. 419-427. 


\section{REFERENCES}

1. Zinoveva, N. A., A. V. Melerzanov, E. V. Petersen, N. Klimyuk, N. A. Volkova, A. S. Duh, I. A. Trusova, E. Volf, and G. Brem. 2014. Ispolzovanie transennyih Gal-ko sviney v ksenotransplantatsii: problemyi i perspektivyi - The use of transgenic Gal-ko pigs in xenotransplantation: problems and perspectives. Selskohozyaystvennaya biologiya - Agricultural Biology, 2:42-49 (in Russian).

2. Maniatis, T., E. Frich, and D. Sembruk. 1984. Molekulyarnoe klonirovanie - Molecular cloning. Moscow, Mir, 479 (in Russian).

3. Aytnazarov, R. B., N. S. Yudin, R. S. Kirilchuk, N. N. Kochnev, S. P. Knyazev, and M. I. Voevoda. 2016. Opredelenie chisla kopiy endogennyih retrovirusov tipa A u domashnih sviney i dikih kabanov - Determination of the copy numbers of type A porcine endogenous retroviruses in domestic pigs and wild boars. Vavilovskiy zhurnal genetiki i selektsii - Vavilov Journal of Genetics and Breeding. 20(6):756-761 (in Russian).

4. Ryabinin, V.E. 2015. Problemyi i perspektivyi sozdaniya ekstrakorporalnyih sistem podderzhki funktsionalnogo sostoyaniya pecheni - Problems and prospects of creating extracorporeal systems to support the functional state of the liver. Biomeditsinskaya himiya-Biomedical chemistry, 61(5):545-559 (in Russian).

5. Skaletskiy, N. N. 1985. Vliyanie kultivirovaniya ostrovkovyih kletok podzheludochnoy zhelezyi na ih vyizhivanie $\mathrm{v}$ organizme ksenogennogo retsipienta - Influence of cultivation of islet cells of the pancreas on their survival in the organism of the xenogeneic recipient. Transplantatsiya organov - Organ transplantation. Kyiv, Kolos, 219-220 (in Russian).

6. Sokolov, V. P., and V. V. Dzheme

7. linskiy. 1989. Vyidelenie vyisokomolekulyarnoy eukarioticheskoy DNK s ispolzovaniem atsetata kaliya - Isolation of high molecular eukaryotic DNA using potassium acetate. Molekulyarnaya genetika, mikrobiologiya i virusologiya. - Molecular genetics, microbiology and virology. 6:45-46 (in Russian).

8. Yudin, N. S., R. B. Aytnazarov, and V. I. Ermolaev. 2011. Endogennyie retrovirusyi svini: naskolko velik risk infektsii pri ksenotransplantatsii? - Endogenous retroviruses of pig: how great is the risk of infection with xenotransplantation. Vavilovskiy zhurnal genetiki i selektsii - Vavilov Journal of Genetics and Breeding. 15(2):340-350 (in Russian).

9. Guo, Fei., Xiaowei Xing, Wayne J. Hawthorne, Qiong Dong, Bin Ye, Juan Zhang, Qi Liang, and Wei Nie. 2014. Characterization of PERV in a new conserved pig herd as potential donor animals for xenotransplantation in China. Virology Journal. 11:212-221 (in English).

10. Chak-Sum, Ho., S. Erin, P. Rochelle, W. Gregory, M. Martens, B. Lawrence, J. Schook, M. Douglas, and M. Smith. 2006. Characterization of swine leukocyte antigen polymorphism by

11. sequence-based and PCR-SSP methods in Meishan pigs. Immunogenetics. 58(11):873-882 (in English).

12. Windt, D. J., R. Bottino, G. Kumar G., M. Wijkstrom, H. Hara, M. Ezzelarab, B. Ekser, C. Phelps, M. Murase, A. Casu, D. Ayares, G. Fadi, R. Lakkis, M. Trucco, and D. Cooper. 2012. Clinical Islet Xenotransplantation How Close Are We? Diabetes. 61(12):3046-3055 (in English).

13. Giraud, S., F. Favreau, N. Chatauret, R. Thuillier, S. Maiga, and T. Hauet. 2011. Contribution of Large Pig for Renal Ischemia-Reperfusion and Transplantation Studies: The Preclinical Model. Biomedicine and Biotechnology. 2011:1-14 (in English).

14. Harrison, I., Y. Takeuchi, B. Bartosch, and J. P. Stoye. 2004. Determinants of high titer in recombinant porcine endogenous retroviruses. J. Virol. 78:13871-13879 (in English).

15. Elliott, R. B. 2011. Living Cell Technologies Towards xenotransplantation of pig islets in the clinic. Curr Opin Organ Transplant. 6:195-200 (in English).

16. Groth, C. G., O. Korsgren, and A. Tibell. 1994. Transplantation of porcine fetal pancreas to diabetic patients. Lancet, 344:1402-1404 (in English).

17. Meije, Y., R. R. Tonjes, and J. A. Fishman. 2010. Retroviral restriction factors and infectious risk in xenotransplantation. Am. J. Transplant. 10(7):1511-1516 (in English). 
18. Nikitin, S. V., N. S. Yudin, and S. P. Knyazev. 2010. Differentiation of wild boar and domestic pig populations based on the frequency of chromosomes carrying endogenous retroviruses. Nat. sci. 2(6):527-534 (in English).

19. Kimsa, M. C., B. Strzalka-Mrozik, M. W. Kimsa, J. Gola, P. Nicholson, K. Lopata, and U. Mazurek. 2014. Porcine endogenous retroviruses in xenotransplantation - molecular aspects. Viruses. 6(5):2062-2083 (in English).

20. Fink, J. S., J. M. Schumacher, S. L. Ellias, E. P. Palmer, M. SaintHilaire, K. Shannon, R. Penn, P. Starr, C. Van Horne, H. S. Kott, P. K. Dempsey, A. J. Raineri, C. Manhart, J. Dinsmore, and O. Isacson. 2000. Porcine xenografts in Parkinson's disease and Huntington's disease patients: preliminary results. Cell Transplant. 9(2):273-278 (in English).

21. Shimatsu, Y., K. Yamada, W. Horii, A. Hirakata, Y. Sakamoto, S. Waki, J. Sano, T. Saitoh, H. Sahara, A. Shimizu, H. Yazawa, D. H. Sachs, and T. Nunoya. 2013. Production of cloned NIBS (Nippon Institute for Biological Science) and $\alpha$-1, 3-galactosyltransferase knockout MGH miniature pigs by somatic cell nuclear transfer using the NIBS breed as surrogates. Xenotransplantation. 20(3):157-164 (in English).

22. Stephenson, F. H. 2003. Calculations for Molecular Biology and Biotechnology. A Guide to Mathematics in the Laboratory. Elsevier Inc, 302 (in English).

23. Hering, B. J., D. K. Cooper, E. Cozzi, H. J. Schuurman, G. S. Korbutt, J. Denner, P. J. O'Connell, H. Y. Vanderpool, and R. N. Pierson. 2009. The international xenotransplantation association consensus statement on conditions for undertaking clinical trials of porcine islet products in type 1 diabetes-executive summary. Xenotransplantation. 16:196-202 (in English).

24. Valdés-González, R. A., L. M. Dorantes, and G. N. Garibay. 2005. Xenotransplantation of porcine neonatal islets of Langerhans and Sertoli cells: a 4-year study. Eur J Endocrinol.153:419427(in English). 